THURSDAY, JANUARY I3, 1876

\section{OUR WATER SUPPLY}

$\Gamma^{-1}$ $\mathrm{HE}$ last Report of the Commissioners appointed to inquire into the Pollution of Rivers has excited a considerable amount of public attention, and the press, in addition to giving its own views on the matters reported on, has printed a considerable number of letters from private persons interested in the question. We have, of course, had the usual remarks about the conflicting statements of scientific witnesses, and a large quantity of ingenuity has been expended in attempts to prove that this conflicting evidence is an indication of the witnesses being so wedded to pet theories that they are unable or unwilling to see facts in their true light, and hence that the best way is to let matters take their course and trust that everything will come right in the end. To a very large portion of the world this conclusion is a most comfortable one to arrive at, as it spares the atepayer and ofiers no offence to the dreaded "vested interest." On the other hand, there is a considerable section of the public which cannot hear that any part of our institutions is not absolutely perfect without being thrown into a state of nervousness and dread, a section well exemplified on the occasion of a former report by a paper which stated that - "We must face the dreadful fact that no amount of filtration can free our water from the nitrates and nitrites which are amongst the most deadly of poisons!"

No person of ordinary common sense can fail to perceive the folly of the alarmist school, but to the nonscientific public the fallacies of those whose cry is stare super vias antiquas are much more difficult to detect. Unfortunately the education through which most of the present generation have gone is not one which can enable them to arrive at any correct judgment as to the value of statements made by one scientific witness as compared with those made by another; the natural result of their education is in fact to cause them to attach a great value to the statements of a man who has a reputation for what is known as "popular science," and to regard the real worker or knower as an amiable enthusiast or eccentric theorist who is so carried away by his fancies that he is quite incompetent to pronounce upon practical matters. The same habit of mind induces them to value the statements of those whom they are pleased to call "practical men," who are generally men having an empiric or imperfect knowledge of certain processes. The result of this is that the opinion of one who has a mere smattering of chemistry, and therefore considers himself qualified to speak on all chemical questions, is pitted against that of one who has devoted his life to chemical and physical science, and the puzzled outsider sits down exclaiming, "Who is to decide when doctors disagree?" Again, this state of things is pretty well known to the people who are put on their trial by the allegations of those appointed to inquire into sanitary affairs, and they know well enough where to lay their hands on those who will make the best of a case entrusted to them ; and we cannot help thinking that if it were possible to tabulate the names of the scientific witnesses called during the last ten years on the side of sanitary reform or on the side

Voc. Arr. - No. 324 of those who considered their interests endangered by it, some curious facts would be brought to light.

A letter from Sir Edmund Beckett, in the Times of January Ioth, illustrates the state of the case remarkably well. The writer, speaking of letters by Mr. Denton and Lord Camperdown, says that if they had heard as much scientific evidence about water purity as he had, one would have been less puzzled and the other less alarmed; and he then goes on to say that-" They would then have known that the late Report is only what every person of experience in hearing such evidence could have predicted with certainty from the constitution of this commission." We may add to this, that any thoroughly competent commission of chemists working with a trustworthy process, could not have arrived at conclusions greatly different from those arrived at by the reporters. The writer then proceeds to say :-

"I have heard eminent scientific men assert on their oaths - and they always add that these things are 'not opinions, but facts'- that the water of a moderate-sized river receiving the unpurified sewage of half a million pecple was perfectly good, potable water for a town not many miles below the sewage-supplying places. That is a specimen of what we may call the impurist philosopher's view of water.

"On the other hand, there is a school which maintains, with equal positiveness, the theory that no length of run (within such distances as we are practically concerned with) purifies sewage by oxidation, but that a particle of sewage, or whatever other learned name they call it, sent into the Thames at Oxford arrives as a particle of sewage at Hampton, and may poison a man in London. It is true that they do not quite like the proposition reduced to those very bare terms, but they cannot deny, when they are pressed by a little cross-examination, that it is the logical consequence of their theory."

We very much regret that the names of the "eminent scientific men" who make the first assertion have not been given, as we should then have some means of ascertaining the value to be attached to their assertions. With regard to the latter statement we think that the writer to a great extent entirely misses the point. Very few scientific witnesses will maintain that Oxford sewage at present reaches Hampton as sewage; the question is, How long will the present state of affairs remain? With our rapidly-increasing population the volume of sewage yearly poured into a river at any one point must increase, as do the number of points at which sewage is poured in; and the questions really asked of the public are--How long do you suppose that this can go on before the river-bed is coated with sewer mud and becomes, as hundreds of streams which a few years back were clear and bright have become, an open sewer? And is it not better to take such measures as shall prevent such a state of things from coming about than to wait until the pollution becomes unbearable?

The writers of the report in question are perfectly well able to fight their own battles, so that we do not think it necessary to enter into any elaborate defence of their suggestions, but we must protest against their being treated as visionaries, and their statements being judged as of no more value than those of the "eminent scientific men" who say that a moderate-sized river can receive the sewage of half a million of people and yet be a "perfectly good, potable water not many miles below the sewage-supplying places." 
We are in no danger of the theory of "sanitas sanitatum omia sanitas" being pushed to excess by sanitary zealots ; and for the present, at any rate, the teaching of the Rivers Pollution Commissioners has been nothing more than "take care of the sewage, and the water supply will take care of itself."

\section{LIEUT. CAMERON IN CENTRAL AFRICA}

THE first detailed news of the latter half of Lieut. 1. Cameron's trans-African expedition was read at the Geographical Society on Monday night, in the form of extracts from letters of the explorer, who intends to remain at Loando until he has a chance of finding a genial climate here. We do not yet possess details sufficient to authorise us in drawing final conclusions as to the results so far as the great problem of Central African drainage is concerned; though we are quite justified in concluding that Lievt. Cameron has proved himself to be possessed of the qualifications of an explorer of the first rank, and that means ought to be found of making still further use of his valuable services. He has not been able to accomplish all he intended when he set out from Ujiji in March 1874 , but he has certainly added very largely to our accurate knowledge of Central Africa. He was not able, owing to the hostility of the natives, and the want of pluck in his followers, to follow the course of the Lualaba in order to ascertain whether or not it joins the Congo. He has, however, obtained data which render it very improbable that the Lualaba and Tanganyika contribute to the Nile system; the only known outlet of the lake, the Lukuga, he has ascertained, flows into the Lualaba. This latter river at Nyangwè is only 1,400 feet above the sea, or 500 feet below the Nile at Gondokoro, and lies in the centre of an enormously wide valley, "which receives the drainage of all this part of Africa, and is the continuation of the valleys of the Luapula and Lualaba." Cameron found that the river, contrary to Livingstone's report, really turns to the west below Nyangwe, and the Arabs report that further down it flows W.S.W. A river, the Lowa, said to be as large as the Lualaba, at Nyangwe, joins it from the northward a short way farther down, besides cther important rivers from the same direction. Cameron failed to make his way to Sankorra, a lake into which the Lualaba falls, and to which "trowser-wearing traders are renorted to come in large sailing-boats to buy palm-oil and dust (probably gold) packed in quills."

Lieut. Cameron traces with considerable minuteness the course of the Lualaba to some distance below Nyangwè. He shows that the true Lualaba in its upper course is the river to the west of Lake Bangweolo, crossed by the Pombeiros in their trading journeys to Cassembe's Town, and that Livingstone's Upper Lualaba is properly called the Luvwa. The river receives many tributaries during its course to Nyangwe, and passes through a number of lakes, so that by the time it reaches its final destination it must be a river surpassed in volume by few others.

All this seems to indicate that the Lualaba reaches the sea on the west coast, but that it does so by means of the Congo it would at present be unsafe absolutely to assert, though if it do not, what other Central West African river is of sufficient size to carry off the immense drainage which the Lualaba evidently represents?
On account of the vexatious obstacles to his course along the Lualaba, Cameron turned southward, and during his journey south and then west to Benguela he made many valuable and accurate observations which will help greatly in filling up that portion of the map of Africa. Some distance south of Nyangwè he came upon a small lake Mohrya, fed by the rains, and apparently isolated from the rest of the water-system, but which is interesting as containing regular lake-villages. $\mathrm{He}$ is inclined to believe that the Albert Nyanza is much smaller than Sir Samuel Baker makes it, and he found that the Lomâmi has no connection with the Kassabe, as shown in the map published by Keith Johnston. In the southward march Cameron passed the sources of the Lulua, which runs into the $Z$ ambesi, whose sources he places in $23^{\circ} \mathrm{E}$. long. and $11^{\circ} \mathrm{I} 5^{\prime} \mathrm{S}$. lat.

Cameron gives the most glowing description of the productiveness of the country through which he has passed; coal was found, gold, copper, iron, and silver are abundant, and he is confident that with a moderate expenditure of capital "one of the greatest systems of inland navigation in the world might be utilised." Multitudes of tropical products abound, and the region is well adapted for the cultivation of extra-tropical ones. A canal, he thinks, of twenty to thirty miles in length, would connect the Congo and Zambesi systems, and the resulting com. mercial advantages would be enormous. So the enthusiastic traveller believes, and whatever may be the results in this direction, the gains which have accrued to accurate geographical knowledge from his journey are such as must earn him the warmest thanks of the friends of science. He has taken 400 observations, "and consequently," as Sir Henry Rawlinson remarked, "has soundly established all the geographical landmarks of the country."

\section{MORELL'S "EUCLID SIMPLIFIED"}

Euclid Simplified. Compiled from the most important French works, approved by the University of Paris and the Minister of Public Instruction. By J. R. Morell, formerly H.M. Inspector of Schools. (London: Henry S. King and Co., 1875.)

FUCLID simplified! "My friend M., with great painstaking, got me to think I understood the first proposition in Euclid, but he gave me over in despair at the second." Had Elia lived in these days of modern geometries perchance he had been a moderate geometer, but his wit might have been dulled. The book before us, however, is not the book we should recommend to a sucking geometer. We look upon it as one of those private ventures which we hope the Association for the Improvement of Geometrical Teaching will extinguish. There is hardly a page without its crop of faults. The title we consider to be a misnomer, for the method of Euclid (the geometer) is departed from altogether. We should look to find in a "Euclid Simplified" something far different from this. The treatise is based upon good geometrical authorities, as will be seen by a reference to the prefatory remarks; it is to the form in which these authorities are presented that we object. Who is the interpreter? A former "H.M. Inspector of Schools." We have been wont to look upon these gentlemen as masters of one or more tongues, and as having a fair acquaintance with the 